\title{
Attitudes towards Smart Phones and Tablets
}

\author{
Ali Akbar Ansarin \\ Department of Language and Literature, Faculty of Persian Literature and Foreign Languages University of Tabriz, Iran \\ E-mail: aansarin@yahoo.com \\ Farahman Farrokhi \\ Department of Foreign Languages and Literature, University of Tabriz, Tabriz, Iran \\ E-mail: ffarrokhi20@yahoo.co.uk \\ Hamid Reza Mahboudi (Corresponding author) \\ Rubbi Rashid Higher Education College, Tabriz, Iran \\ E-mail: hr_mahboodi@yahoo.com \\ Zohreh Adeli Jam \\ Rubbi Rashid Higher Education College, Tabriz, Iran \\ E-mail: Adeli.jam@ut.ac.ir
}

Received: 07-02-2017

Published: 01-09-2017
Accepted: 10-04-2017

doi:10.7575/aiac.ijalel.v.6n.5p.66
Advance Access Published: July 2017

URL: http://dx.doi.org/10.7575/aiac.ijalel.v.6n.5p.66

\begin{abstract}
This paper examines the perceptions of advantages of smart phones and tablets on basic and general English students' language learning, self-sufficiency, and interest using smart phones and tablets at an Iranian university college during one university term. Through a survey administered to 333 basic and general English students and through selective observations and interviews, the following questions were examined: 1) Students' perceived impact of smart phones and tablets on increasing their confidence throughout the course,2) Students' perceived comfort/enjoyment with smart phones and tablets for the students at the beginning and end of the semester,3) Students' perceived impact of devices through a comparison between pre and post survey measures on improvement of reading comprehension, reading speed, vocabulary and spelling, motivation, and preparing them for class tests and quizzes. Tablets were evaluated more positively than smart phones by the students as a means to increase confidence. Both tablets and smart phones were evaluated positively, both as a means of improving students' motivation to learn, and as a means to develop reading comprehension, spelling, and vocabulary. However, students' expectations regarding the impact of such devices on their reading speed, preparation for tests and quizzes, as well as comfort and enjoyment were not met.
\end{abstract}

Keywords: Smart Phones, Tablets, Basic English, General English, Perception

\section{Introduction}

Mobile devices are an integral part of our everyday lives as these devices include numerous electronic products, such as laptops, the new iPads, iPhones, iPods, Android phones and Android tablets. Every day we see more and more people with an iPhone, Android-based phone, or other smartphones.

According to Gartner Research (2012), worldwide smartphone sales reached 472 million units in 2011, which is a 58 percent increase over 2010. Smart phones are growing in popularity and changing the way we live our lives. We no longer memorize phone numbers because we carry a phonebook in our pockets. We rarely ask for driving directions because smart phones include GPS with maps. We are connected 24/7 through email, text messaging, and now even video chat. Smartphones provide instant access to information wherever we go.

There's another game changer on the horizon - tablets. Forrester Research (2014) predicts that by 2016 tablets will outsell desktop computers in the US. Tablets are somewhere between a smartphone and a laptop. They are webconnected with touch-screen interfaces like smartphones, but they feature the screen real estate of laptops

According to November 30, 2015 reports of Internet World Stats (IWS), Iran ranks the first in internet usage in the Middle East (46.8\%). Internet users (including internet cafe users): 23 million (2007), 43-million (2012), internet penetration is $53 \%$ across the population and $77 \%$ in Tehran, according to government data. About 11 million Iranians have mobile Internet access (2014). Iran's National Internet Development Centre (2015) says internet penetration stood at $73 \%$ in 2015, making Iran one of the biggest internet users in the Middle East. As of 2014, 67.4 percent of Iranian young people (between the ages of 15-29) use the internet. Iran's telecom sector presents opportunities and challenges 
in 2015. The telecoms market is very important to Iran economy and provides one of the largest non-oil based revenue streams. Improving and expanding telecoms infrastructure has been the focus of investment in recent years, and Iran's tech-savvy, young population is eager to take up next generation services. Students at all levels use their smart phones and tablets. They use them for texting, playing games and benefitting from their language learning applications. They are permitted to use them during most language lessons, but not during exams. They can even take calls and step out of the room to return calls. Tablets are not only permitted but also required. This means even bigger multimedia textbooks, video and interactive features, educational applications and support.

This paper examines the interplay of teaching and learning factors that lead to optimal use of technology-enhanced language learning as perceived by classroom participants during one semester in the context of Iran, where smart phones and tablets, in addition to the modern language Laboratories, are becoming increasingly popular despite sanctions.

\section{Review of the Related Literature}

Numerous pilot projects and research papers concerning mobile learning were only able to define it as a fuzzy concept. However, by taking mobile-learning one step further, Geddes (2004), was able to introduce the acquisition of knowledge through the use of mobile technologies regardless of time and space. Therefore, able to declare their presence everywhere and anytime, mobile technologies started to be considered as the subtle, autonomous accompany of human being (Jee, 2011). As a burgeoning subdivision of the e-learning movement mobile learning or m-learning applications in different Asian and European contexts reveal the benefits and challenges of applied fusions of mobile assisted language learning (MALL) (Chinnery, 2006). A variety of MALL applications have shown to be mostly positive for students learning a foreign language (Ally et, al., 2007). Project developed by the Stanford Learning Lab using mobile devices (e.g., mobile phones) followed by the works by Thornton and Houser (2002, 2003, 2005), Kiernan and Aizawa (2004), Levy and Kennedy (2005) have been shown to be as effective academically as regular (offline/traditional) classes. Mielo (2005) reported the newest technology of the time as combination of mobile and weblogging. He further defined mobloging as a potential application in language learning offering a simplified and flexible student-teacher communication (Dias, 2002 a, 2002 b; Levy \& Kennedy, 2005). Song and Fox (2005) found major enhancements in learner performance doing language tasks. Others also were able to use mobile devices for teaching pronunciations and listening skills (Uther, Zipetria, Uther \& Singh, 2005). Allowing learners to express themselves in a variety of circumstances and have better engagement with learning tasks along with improved interaction capabilities, mobile devices have also been captured beneficial in the recent study carried by Sole, Calic, and Neijmann (2010). Considerable effect of mobile phones on boosting language ability of learners was illustrated in the MALL research project report in 2009. Najmi (2015) found that text messaging and using mobile phones for pedagogical purposes can be an exquisite facilitator for both teachers and learners and it has the capabilities of being used more than today. The privacy and freedom obtained while using mobile devices was identified to have a major impact on students' improved overall language proficiency. As reported by Leis et al. (2015), students who use smartphones in the classroom are inclined to study more in their free time and show signs of autonomy and consider ways to improve their own study habits and language proficiency.

According to Agha and Ayse (2011), although m-learning is able to impact the learning environment allowing learners and teachers to utilize their free time selectively, technologically and pedagogically, it is still in early stage of development. Despite its major impact on changing dead time into productive activity, Seong and Broga (as cited in Bruck et. al., 2012) argued that, limitations of mobile devices, "such as small screen size, variations in platforms, mobile networks, and presentation of information to device in a reliable and friendly manner could be identified as blocker to the uptake of learning" (p.529). However, the above mentioned issues have started to be addressed by the introduction of the new category of mobile devices namely 'future mobile or smart phones' (Mockus, et. al., 2011). Smart phones as stated by Woodill (2011) having the same functionality as lap tops and computers in web surfing and productivity tools such as office are recently seen as the most appropriate device or platform for mobile learning. Similarly, Rosenberg (2010) asserts the centrality of smart phones as prominent mobile learning devices. When the idea of mobile learning is narrowed to focus on the smart phones and more recently the new tablet devices such as iPad, we are able to provide learners with appropriate and just-in-time form of the learning experience in a much more powerful and focused manner (Shearer, 2010). Mochus, et. al., (2011) also stressed the post-pc era feature (i.e., always on and connected) of the new iPad and iPhone generations having provided us with endless access to vast number of applications which can vary in educational setting from interactive lessons to study aids and productivity tools. To add another dimension to the superiority of iPad over other mobile devices such as smartphones the Abilene Christian University announced iPad versus smartphone research findings in 2011, including 60 percent favoritism on part of iPad version of mobile devices for studying and test preparation due to large screen size.

In recent years the introduction of tablets such as ipad or galaxy have given rise to the introduction of new version of mobile learning namely micro-learning to address the problem of content delivery and user interaction which could add up to m-learning usability (Bruck, et. al., 2012). Micro-learning pedagogy on the other hand according to Kovacher, et. al. (2011) focuses on short-term and informal learning activities when the learner needs the knowledge to solve a problem. By breaking mobile-learning content into smaller chunks with the higher interaction level and immediate feedback after user action, micro-learning elevates the limited potential of m-learning with long learning sequences, large chunks of information and low degrees of interactivity (Simon, 1974; Cowen, 2011). 
If we take one step further, it would be possible to consider the advantage of tablets beyond their content delivery style and high interaction level. The results of the research carried by the college of engineering at Virginia Tech, by Kothaneth, Robinson, and Amelik (2011) showed that tablets are also beneficial to all kinds of learning styles since, they are able to address learners' different learning strategies and styles by adding visual and reading/writing artefacts altogether to the process of learning and establish the relationship between technology use and specific style preferred by the learner. Other benefits and advantages proposed by tablets were revealed by Sheehy, et al. (2005) to be the promotion of curriculum access and improving learners' motivation and communication.

However, for the purpose of identification of the above mentioned benefits and advantages of technology enhanced language learning, perceptions and attitudes towards the effects of mobile devices, specifically tablets and smart phones, need to be taken into account and analyzed through the eyes of the learners to get a glimpse on the effect of the technology on their language learning process. Moreover, observation and interview of the community within classrooms, namely, teachers and students, as they are using smart phones and tablets, would throw some light on the strengths and weaknesses of such devices. This study was conducted at the University College of Rubbi Rashid situated on the northwest of Iran. Although research of a similar nature has been done in other countries, the present study by following 333 university students complements others and it provides another avenue for examining the present language situation in a country, where despite sanctions and once considered rare and sought-after, Apple and other US computer products are now de rigueur among those who can afford them.

\section{Methodology}

This study aimed to focus on qualitative aspect of learning and teaching and matters relating to effectiveness rather than quantitative aspects and matters relating to efficiency. It relies heavily on students reports about their learning experiences. Students' understanding and attitudes are valuable fields of study in their own right. It is embedded in a specific educational setting that influences its success. Learners, the actual users of electronic devices, define to a large extent what success is in a particular context. It was thus crucial to our understanding of the functioning of smartphones and tablets to take learners' experiences and attitudes into account.

Therefore, based upon the goals of the study, researchers tried to focus on the following questions:

1. According to students, what is the perceived impact of smart phones on increasing their confidence throughout the course?

2. According to students, what is the perceived impact of tablets on increasing their confidence throughout the course?

3. According to students, what is the perceived comfort/enjoyment with smart phones for students at the beginning and end of the study?

4. According to students, what is the perceived comfort/enjoyment with tablets for students at the beginning and end of the study?

5. According to students, what is the perceived impact of mobile devices between pre and post survey measures on improving reading comprehension, reading speed, vocabulary and spelling, motivation, and preparing them for class tests and quizzes?

\subsection{Participants}

The study was carried out in Rubbi Rashid Higher Education College in Tabriz with 333 Biotechnology students, all of whom were under 25 years old. 80\% were females; 20\% were males, doing Basic English One and Two and Biology students doing General English. They had to do Basic English One, Basic English Two, and general English as a prerequisite for specialized English during Fall 2011.The age of the instructors was34 and 40. During the training sessions, the instructors and the students agreed to become actively involved during the lab sessions and not just be silent bystanders.

\subsection{Instruments}

Pre- and post-study surveys were administered to students (See Appendix for student pre- and post-study surveys.) These surveys consisted of a number of background questions, and three multi-item scales, or sections: confidence using smart phones and tablets, perceived benefit of using smart phones and tablets, and comfort with and enjoyment of using smart phones and tablets. All respondents were measured on a four-point scale: confidence in smart phones and tablets, with $4=$ "very confident" and $1=$ "not at all confident"; predicted benefit for various factors, with 1 = "none" and $4=$ "a lot"; and comfort and enjoyment, with $1=$ "none" and $4=$ "a lot." In addition, the surveys included openended follow-up questions asking for more detailed information on the use of smart phones and tablets and positive and negative effects of these devices.

The pre-study survey was administered during the first week of classes. The post-study survey was administered during the last week of classes.

\subsection{Procedure}

The semester before the study began, the instructors spent 2 hours of negotiation on how to use the language lab and how to integrate smart phones and tablets into their classes. The teachers agreed to include at least five tasks with stepby-step instructions in the syllabi so that students could easily follow along. Sample tasks provided for the teacher included the following: 1) use smart phone and tablet applications, such as exercises, games, and content, 2) receive 
instruction on listening to materials, looking the new words up and note taking, recording voices, using pair work through text messaging, playing interactive games, Yahoo Chatting, and online searching 3) use foreign language keyboards or Microsoft Word/Pages for writing exercises, mailing, 4) do web search assignment, and 5) use Speakernotes Lite. All sample tasks could be done using the tablets and smart phones. Teachers could also use other types of tablet and smart phone applications that suited the syllabi. Class syllabi were checked by the researchers for appropriateness before the semester began.

Teachers were creative in order to effectively use smart phones and tablets in the curriculum to improve student learning. Smart phones included iPhones, Samsung, HTC, Nokia, Motorola and the tablets included iPads, Samsung Galaxy Note, and Sony Tablets.

In addition to taking pre and post surveys, teachers and students were observed while helping with teaching the smart phone and tablet apps in the language laboratory. Students were observed in the language laboratory three times during the term. One student per class was interviewed per observation session, depending upon whether he or she appeared to be engaged or unengaged in classroom work. All observers agreed to observe the same class and designed an observation instrument to examine the number and type of equipment in the room, the type of tasks observed, the amount or occurrence of the following: use of target language by students, the amount of language learning, and the frequency of interaction from student to student, teacher to student,. They also agreed on the results of one individual interview with one of the students in the class in which the student was asked about one activity and her satisfaction with the technical training and assistance as well as the language learning potential of the activity. Finally, all observers came to a consensus on the meaning of some options reaching $100 \%$ agreement and observed the rest of the classes using similar instruments.

\section{Results}

The survey included the general questions, pre-survey questions, and post-survey questions. The general question section included several questions to gather demographic data which helped characterize the sample audience. These questions related to the students' mobile devices and how/how often they were used, how long they had them, what they were used for, and how much they depended on them ( Appendix A). Students were able to select one answer among the alternatives. Nearly all those who participated in the study had either a smart phone or a tablet. Only a few had both. Answers to general question one showed that the majority of students had smart phones (185 girls and 55 boys) and 20 students had tablets ( 15 girls and 5 boys), and 43 students had both devices (33 girls and 10 boys) (Appendix D, Figure 1). General question two showed that nearly all of them were comfortable with their devices (133 girls and 44 boys were very comfortable, 167 girls and 55 boys were somewhat comfortable (Appendix D, Figure 2). More than 226 students (174 girls and 52 boys) said they had been using their devices more than 3 years in general question 3 . And 133 students (103 girls, 30 boys) said they had been using them for more than 2 years (Appendix D, Figure 3). In question four, about 185 students said they would buy the device if they found them useful and 175 students claimed they would buy them if they were popular (Appendix D, Figure 4). In general question five, 125 girls and 87 boys claimed they used their device for text messaging; 101 girls and 30 boys said they used them for learning English; and 57 girls and 17 boys claimed they used them for making calls (Appendix D, Figure 5). Figure six (Appendix D) shows that the students would use their devices mostly for 1-2 hours a day if they had access to internet. It is notable that a great majority of students (287 students) felt they could live without a mobile device (Appendix D, Figure 7). Finally, figure eight shows that about half of the students said they used their mobile devices less than an hour a day and another half said they used them for more than one hour a day (Appendix D, Figure 8).

For pre and post survey questions all descriptive statistics, correlations, Chi-Square Tests and Symmetric Measures were calculated using SPSS. The concern of the first research question was to examine the perceived impact of smart phones on increasing students' confidence throughout the course. For this purpose the researcher ran some descriptive statistics. Table 1 presents the descriptive statistics for students' attitudes towards smart phones.

Table 1. Descriptive Statistics for Students' attitudes towards smart phones

\begin{tabular}{lllllllllll}
\hline $\begin{array}{l}\text { Approx. } \\
\text { Sig. }\end{array}$ & $\begin{array}{l}\text { Contingency } \\
\text { Coefficient }\end{array}$ & $\begin{array}{l}\text { Asymp. } \\
\text { Sig. } \\
\text { (2-sided) }\end{array}$ & $\begin{array}{l}\text { df } \\
\text { Square }\end{array}$ & $\begin{array}{l}\text { Pearson } \\
\text { Chi- } \\
\text { Total }\end{array}$ & $\begin{array}{l}\text { Not } \\
\text { at } \\
\text { all }\end{array}$ & $\begin{array}{l}\text { Not } \\
\text { very }\end{array}$ & $\begin{array}{l}\text { Somewhat } \\
\text { confident }\end{array}$ & $\begin{array}{l}\text { Very } \\
\text { confident }\end{array}$ & $\begin{array}{l}\text { Variable } \\
\text { group }\end{array}$ \\
\hline .300 & .074 & .300 & 3 & 3.664 & 333 & 19 & 47 & 139 & 128 & pre \\
\cline { 4 - 9 } & & & & & 333 & 12 & 36 & 146 & 139 & post \\
\hline
\end{tabular}

As data in table 1 indicates, in the pre-survey, 128 students were very confident, 139 were somewhat confident, 47 were not very confident, and 19 were not confident at all. In the post survey, 139 students were very confident, 146 were somewhat confident, 36 were not very confident, and 12 were not confident at all. The resulting Pearson Chi-square shows the difference is not noticeable. As a result, the students' confidence towards their smart phones did not significantly increase. 
However, descriptive statistics for pre- and post-study of students' attitudes towards tablets showed an increase in students' confidence in the post survey (table 4-2).

Table 2. Descriptive Statistics for Students' attitudes towards tablets

\begin{tabular}{lllllllllll}
\hline $\begin{array}{l}\text { Approx. } \\
\text { Sig. }\end{array}$ & $\begin{array}{l}\text { Contingency } \\
\text { Coefficient }\end{array}$ & $\begin{array}{l}\text { Asymp. } \\
\text { Sig. } \\
\text { (2-sided) }\end{array}$ & $\begin{array}{l}\text { df } \\
\text { Searson } \\
\text { Square }\end{array}$ & Total & $\begin{array}{l}\text { Not } \\
\text { at } \\
\text { all }\end{array}$ & $\begin{array}{l}\text { Not } \\
\text { very }\end{array}$ & $\begin{array}{l}\text { Somewhat } \\
\text { confident }\end{array}$ & $\begin{array}{l}\text { Very } \\
\text { confident }\end{array}$ & $\begin{array}{l}\text { Variable } \\
\text { group }\end{array}$ \\
\hline .000 & .280 & .000 & 3 & 56.556 & 333 & 78 & 119 & 57 & 79 & pre \\
\hline & & & & & 333 & 28 & 77 & 85 & 143 & post \\
\hline
\end{tabular}

Research question 1 examined the students' level of confidence with smart phones and tablets. The increased level of confidence with those categories reported by students was not astonishing since practice makes perfect and the students who had not previously experienced such activities in their classes felt they had learned new things as a result of incorporating technology in their language lessons. Many students reported that the classes were very helpful and that they helped them practice language skills more effectively. However the descriptive statistics for students' attitudes towards smart phones showed that the t-value did not allow us to reject the null hypothesis, but there was a trend in the expected direction. That is, the difference found was important and worth our consideration. Reportedly, the reason why the difference was not significant was due to students' misbeliefs about the functions of their phones and the common fallacy among them that phones were just suitable for calling, sending, and receiving messages per se ( e.g., " they are telephones."). However, students' attitudes towards tablets showed an increase in their confidence. Many students noted that they had found tablets more suitable and adequate for their language learning purposes. Hence, the students gained higher degree of satisfaction with tablets rather than smart phones. Most students reported that it was much more intimate than a laptop, and it was much more capable than a smart phone (see Figure 1). These findings are consistent with the opinion of Steve Jobs (2010) who described the iconic iPad tablet as a device fitting somewhere between laptops and smartphones. Consistently with this, Gottheil (2013) argues that a tablet provides a better browsing and email experience than smartphones. Tablets also provide a wider soft keyboard to make typing easy, and a larger screen to read books, play games, write e-mail or view websites. The emergence of tablets in 2010 had a ripple effect on laptops, especially netbooks, shipments of which have slowed down due to the growing interest in tablets.

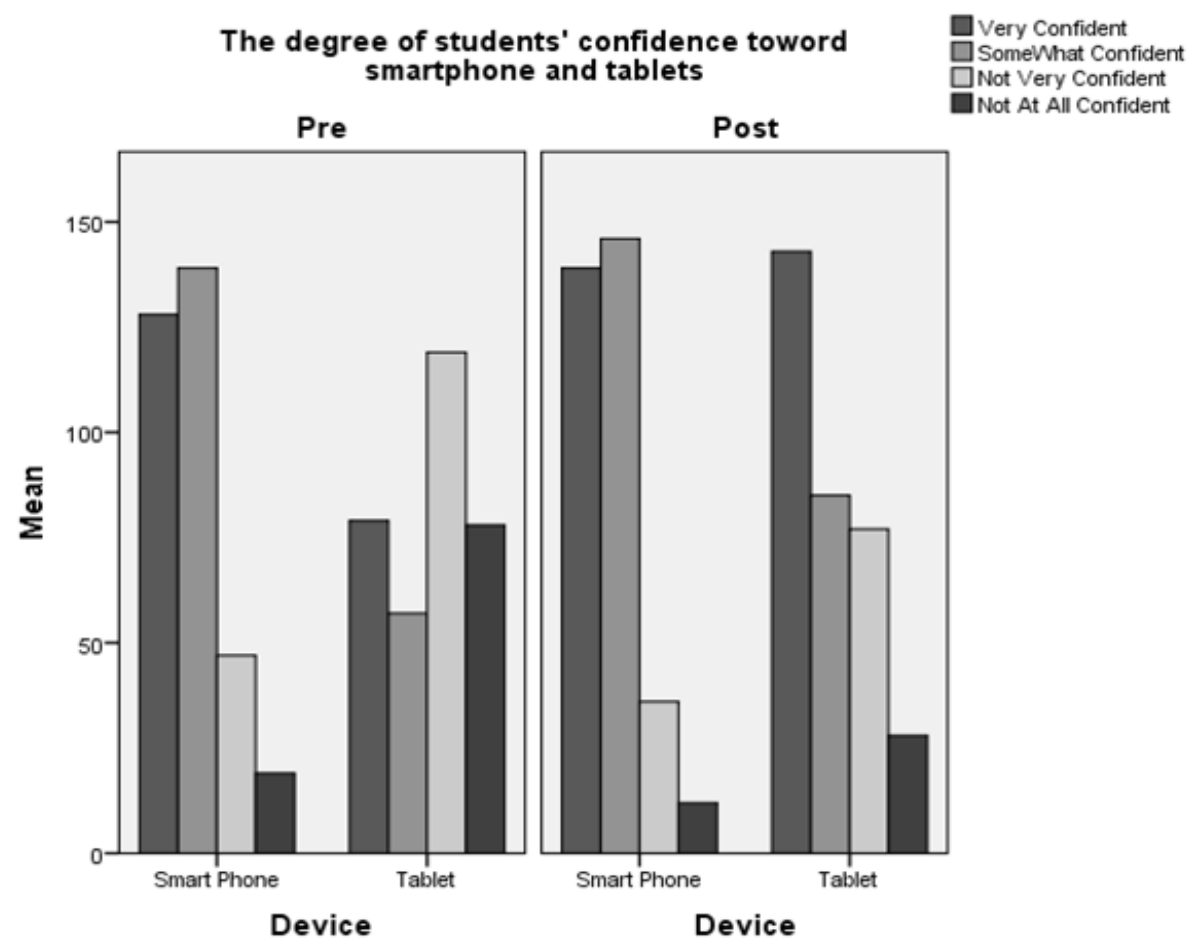

Figure 1. Students' perceived level of confidence between pre and post survey with smart phones and tablets (Q. 1)

Research question 2 asked, "According to students, what is the perceived comfort/enjoyment with smart phones and tablets for students at the beginning and end of the term?" Students' expectations regarding the impact of mobile devices on their comfort and enjoyment were not met, as evidenced by the decrease on their perceived benefit in that category at the end of the semester. This means that students did not enjoy mobile devices as much as they had predicted (Figure 2). A summary of student comments from the questionnaire reveals a high frequency of negative comments. Among the negative comments, the most frequent were about the time limitation, technical problems, their partner's inability to cooperate, their not being accustomed to working with their mobile devices in formal contexts, and their professor's failure to solve the technical problems they had encountered while working with their devices. 
How much do you enjoy using your devic

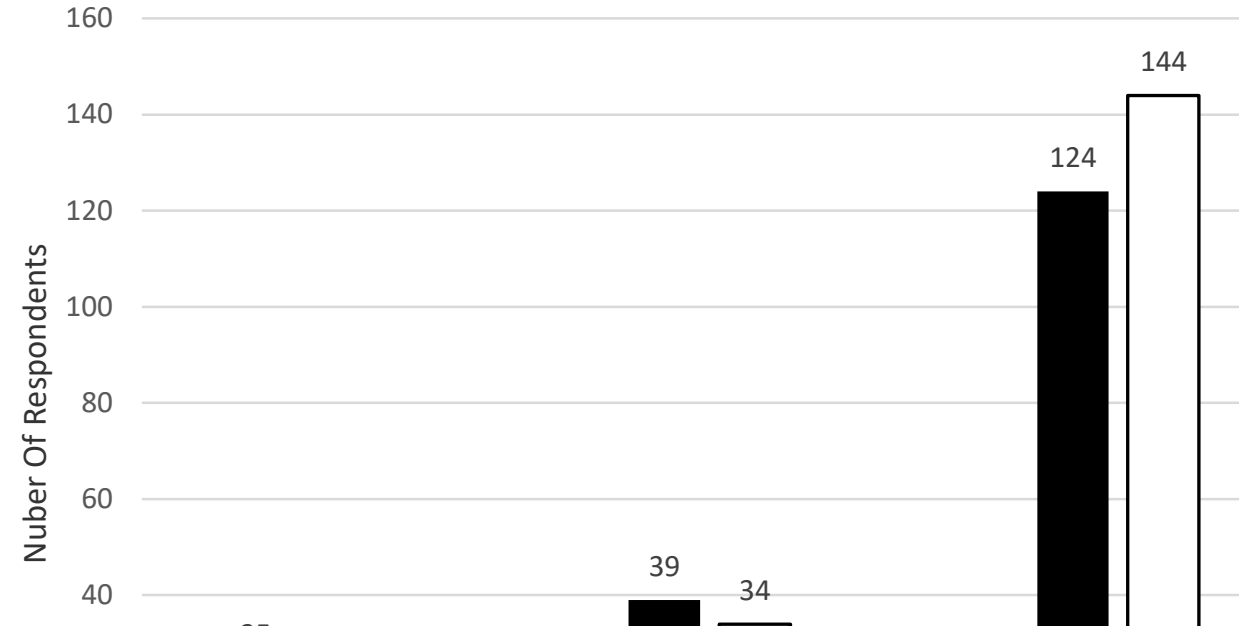

Figure 2. Student's perceived impact of smart phones and tablets on their comfort/enjoyment (Q. 2)

Research question 3 asked, "According to students, what is the perceived impact of mobile devices between pre and post survey measures on improving reading comprehension, reading speed, vocabulary, spelling, motivation and preparing them for class tests and quizzes?" Unlike the negative findings discussed under question two, students' expectations regarding the impact of mobile devices on their reading comprehension were met, as evidenced by the significant increase on their perceived benefit at the end of the semester (see Table 3, Figure 3). These results are in line with the opinion of those scholars who believe that technologies provide equal or greater benefit than traditional means for aiding readers with reading comprehension (Ghizan 2012; Stearns, 2012; Sotoudehnama, 2013; Zarei, 2012; Wright et al., 2013; Giron-Garcia, 2015).

Table 3. Results of inferential statistics for pre and post survey questions

\begin{tabular}{|c|c|c|c|c|c|c|c|c|c|}
\hline Device & Sig. (2-sided) & df & $\begin{array}{l}\text { Pearson Chi- } \\
\text { Square }\end{array}$ & Total & $\begin{array}{l}\text { Too } \\
\text { little }\end{array}$ & little & $\begin{array}{c}\text { about } \\
\text { right }\end{array}$ & a lot & $\begin{array}{l}\text { Variable } \\
\text { group }\end{array}$ \\
\hline \multirow{3}{*}{$\begin{array}{c}\text { Developing reading } \\
\text { speed }\end{array}$} & \multirow[t]{3}{*}{.188} & \multirow[t]{3}{*}{3} & \multirow[t]{3}{*}{4.793} & 333 & 135 & 117 & 48 & 33 & post \\
\hline & & & & 333 & 158 & 114 & 38 & 23 & pre \\
\hline & & & & 666 & 293 & 231 & 86 & 56 & Total \\
\hline \multirow{3}{*}{$\begin{array}{l}\text { Developing reading } \\
\text { comprehension }\end{array}$} & \multirow[t]{3}{*}{.018} & \multirow[t]{3}{*}{3} & \multirow[t]{3}{*}{10.013} & 333 & 120 & 103 & 43 & 67 & post \\
\hline & & & & 333 & 157 & 96 & 33 & 47 & pre \\
\hline & & & & 666 & 277 & 199 & 76 & 114 & Total \\
\hline \multirow[t]{3}{*}{ Improving Spelling } & \multirow[t]{3}{*}{.000} & \multirow[t]{3}{*}{3} & \multirow[t]{3}{*}{109.745} & 333 & 93 & 0 & 143 & 97 & post \\
\hline & & & & 333 & 123 & 67 & 56 & 87 & pre \\
\hline & & & & 666 & 216 & 67 & 199 & 184 & Total \\
\hline \multirow{3}{*}{$\begin{array}{l}\text { Developing } \\
\text { vocabulary }\end{array}$} & \multirow[t]{3}{*}{.001} & \multirow[t]{3}{*}{3} & \multirow[t]{3}{*}{16.979} & 333 & 182 & 69 & 47 & 35 & post \\
\hline & & & & 333 & 202 & 89 & 27 & 15 & pre \\
\hline & & & & 666 & 384 & 158 & 74 & 50 & Total \\
\hline \multirow{3}{*}{$\begin{array}{l}\text { Developing student } \\
\text { motivation to learn }\end{array}$} & \multirow[t]{3}{*}{.000} & \multirow[t]{3}{*}{3} & \multirow[t]{3}{*}{39.971} & 333 & 113 & 162 & 35 & 23 & post \\
\hline & & & & 333 & 192 & 113 & 15 & 13 & pre \\
\hline & & & & 666 & 305 & 275 & 50 & 36 & Total \\
\hline \multirow{3}{*}{$\begin{array}{c}\text { Preparing students } \\
\text { for class tests and } \\
\text { quizzes }\end{array}$} & \multirow[t]{3}{*}{.584} & \multirow[t]{3}{*}{3} & \multirow[t]{3}{*}{1.946} & 333 & 105 & 98 & 67 & 63 & post \\
\hline & & & & 333 & 118 & 101 & 61 & 53 & pre \\
\hline & & & & 666 & 223 & 199 & 128 & 116 & Total \\
\hline \multirow{3}{*}{$\begin{array}{c}\text { Increasing } \\
\text { comfort/enjoyment }\end{array}$} & \multirow[t]{3}{*}{.455} & \multirow[t]{3}{*}{3} & \multirow[t]{3}{*}{2.617} & 333 & 134 & 144 & 34 & 21 & post \\
\hline & & & & 333 & 145 & 124 & 39 & 25 & pre \\
\hline & & & & 666 & 279 & 268 & 73 & 46 & Total \\
\hline
\end{tabular}




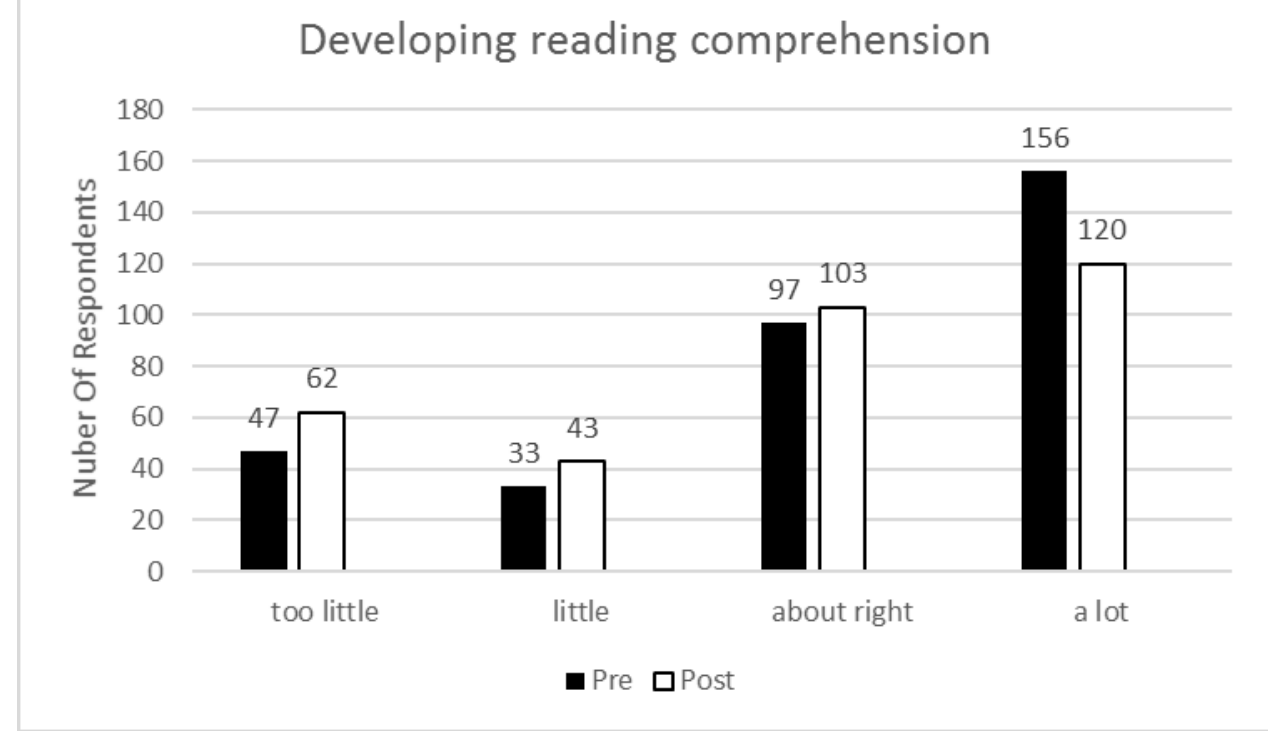

Figure 3. Students' perceived impact of devices on developing reading comprehension (Q. 3)

Research question 3 also seeks students' perceived impact of mobile devices on their reading speed. Unlike the positive findings discussed for reading comprehension, students' expectations regarding the impact of mobile devices on their reading speed were not met (Table 3, Figure 4). The students did not find mobile devices beneficial for the same reasons they had expressed among their negative comments. These results are not consistent with the findings of Ghizan (2012) which indicated that instructional soft wares contributed to the reading speed of students. However, these findings are more in line with the opinion of Just and Carpenter (1987) who argue that speed-reading skill is not at all perceptual but conceptual. It is only for the familiar topic that readers increase their speed rate. After all, the most common experimental finding is that silent reading from screen is significantly slower than reading from paper (Kak, 1981; Muter et al., 1982; Wright and Lickorish, 1983; Gould and Grischkowsky, 1984; Smedshammar et al., 1989).

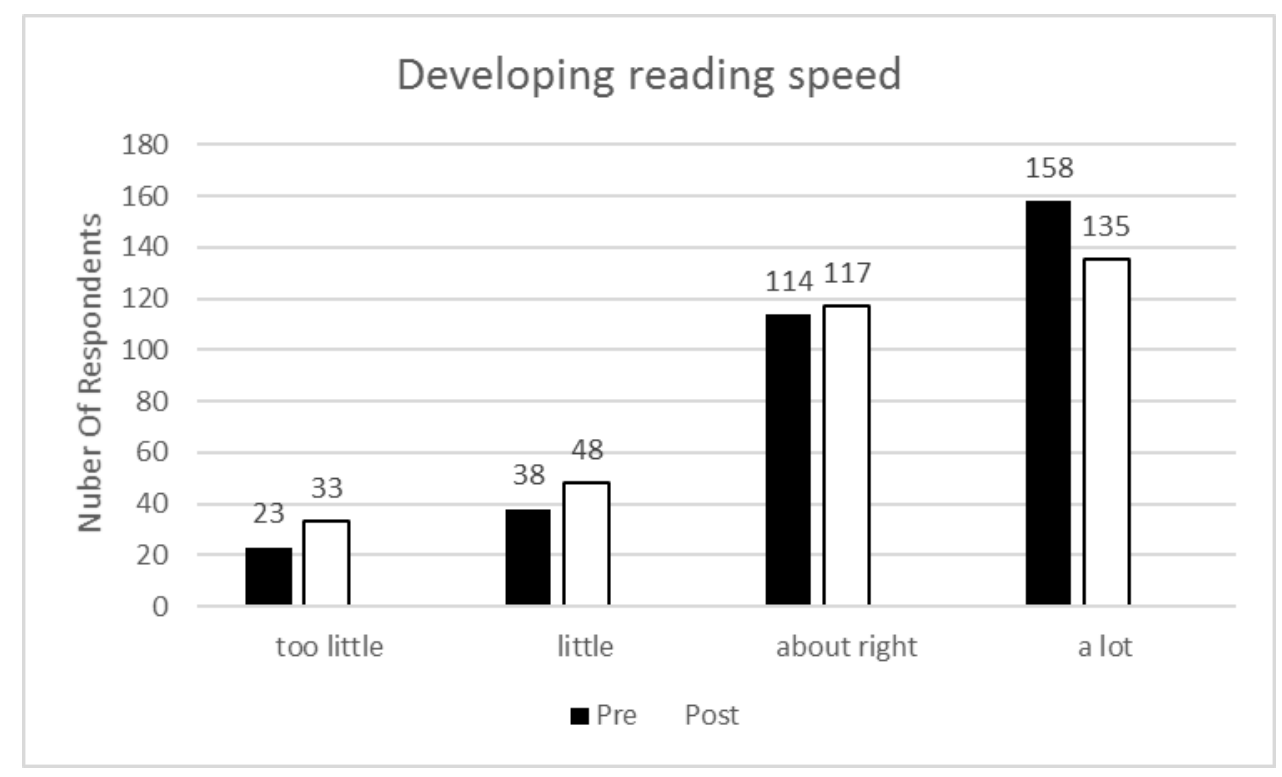

Figure 4. Students' perceived impact of devices on reading speed (Q. 3)

Regarding vocabulary and spelling, students' perceived benefit of mobile devices showed a significant increase in those categories at the end of the semester (Table 3, Figure 5) and (Table 3, Figure 6). Qualitative data gathered provided more information about question three. There were abundant positive comments about progress in vocabulary and spelling (e.g., "mobile devices allow us to eliminate our uncertainty about the meanings of words, spelling, and pronunciation, they are more user-friendly than books, and learning in such classes is fun and is it is not tiring"). 


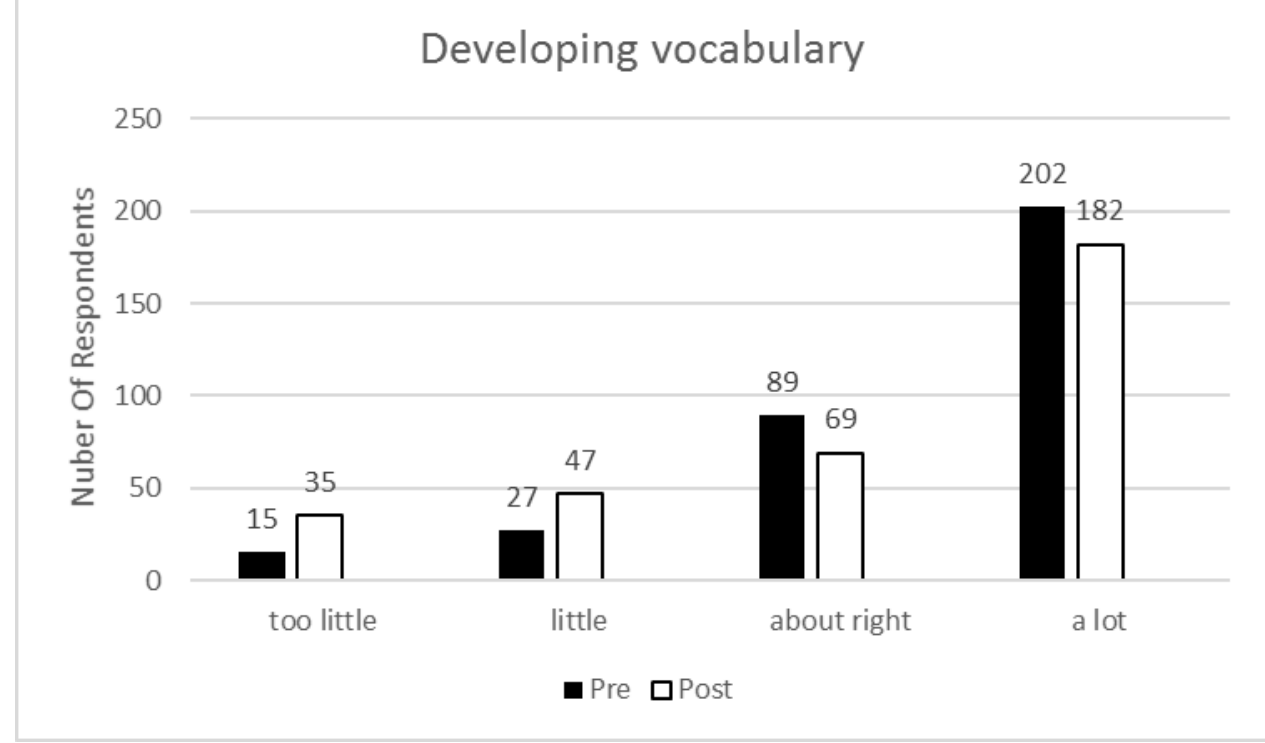

Figure 5. Students' perceived impact of devices on developing vocabulary (Q. 3)

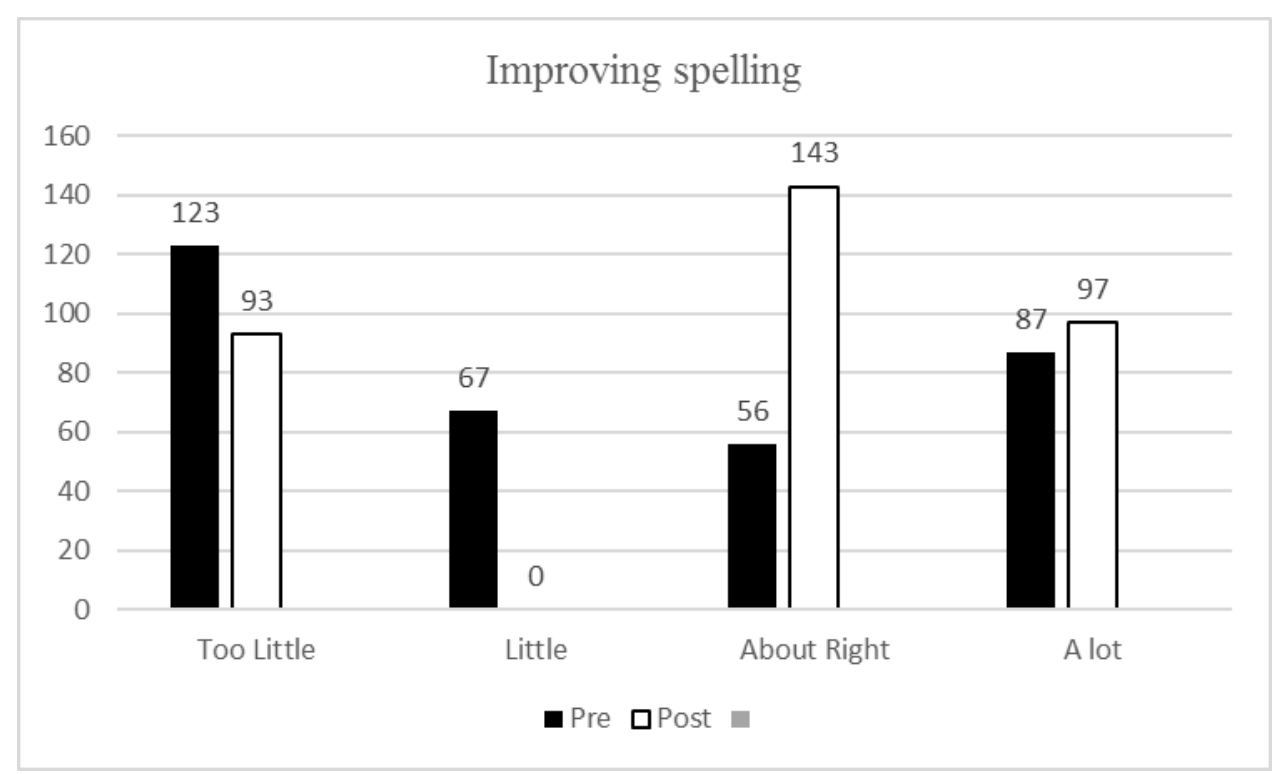

Figure 6. Students' perceived impact of devices on developing spelling (Q.3)

Similar to the positive findings discussed for vocabulary and spelling, students' expectations regarding the impact of mobile devices on improving their motivation to learn were met (Table 3, Figure 6). Students' perceived benefit showed a significant increase from pre to post survey. Perception of benefits by the students is more clearly reflected in their positive comments about the positive impacts of mobile devices on their motivation to attend those classes, which according to them, are different from traditional classrooms. Likewise, smartphones have been shown to improve the spelling and writing ability of students by Najmi (2015). Another study, which is in line with the present study, is by Thornton and Houser (2005). The results indicated that mobile phones can effectively help to learn a foreign language and short message is very useful to teach vocabulary. In a parallel fashion, previous research exploring the impact of mobile access and tablets on students' motivation, self-steam, and learning has found similar positive correlation between students' mobile use and motivation (Kyanka-Maggart, 2013; Vanwelsenaers, 2013; Mockus, 2011). 


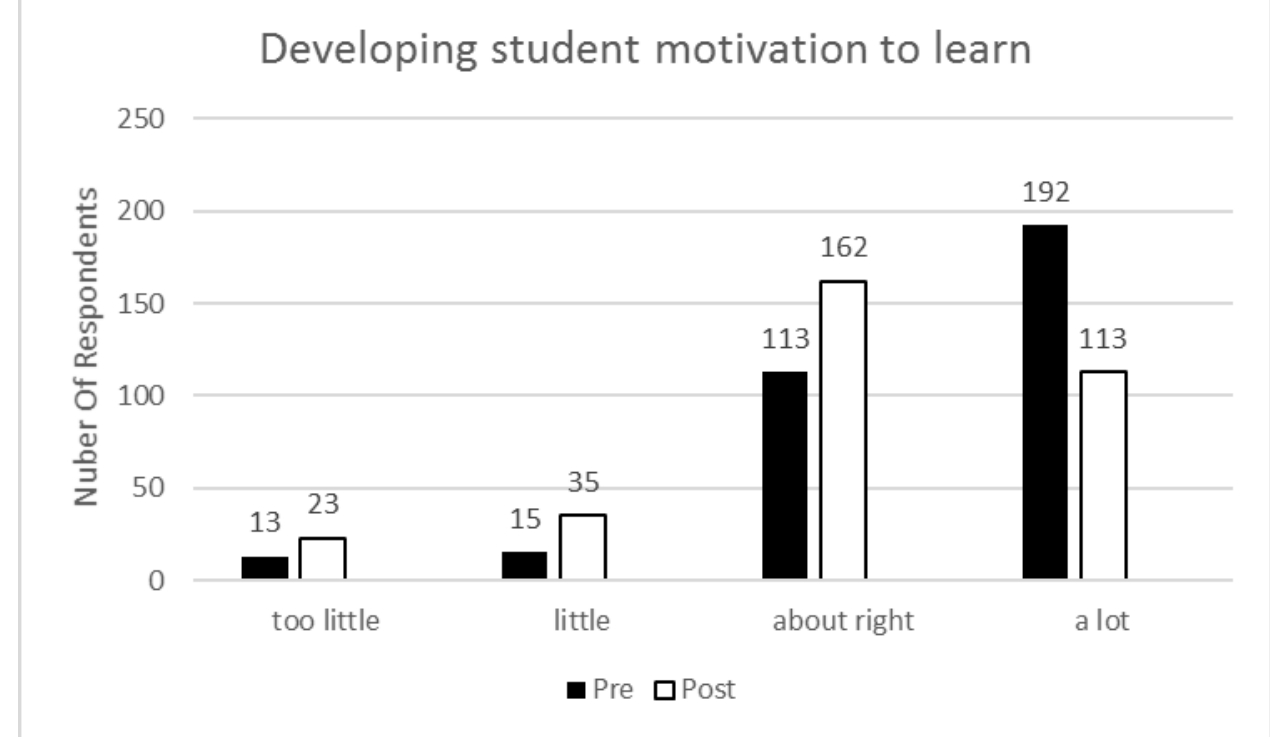

Figure 6. Students' perceived impact of devices on developing motivation (Q. 3)

However, students didn't find mobile devices beneficial to their tests and quizzes as much as they had anticipated (Table 3, Figure 8). As shown in table $3(\mathrm{t}=0.58 ; \mathrm{df}=3 ; \mathrm{p}<.05)$, there was not a significant difference between the pre and post survey measures and mobile devices could not meet the students' expectations. Similar findings have been reported by Kuznekoff and Titsworth (2013) who examined the impact of mobile phone usage, during class lecture, on student learning. They found that students who were using their mobile phones frequently during a video lecture scored, on average, 13 percentage points, or a letter grade and a half, lower on a multiple-choice test than those students who were not using their phones. Students who were not using their mobile phones not only did $62 \%$ better on overall note taking, but also recorded 93\% more outstanding answers in their notes than the group of students who were frequently using their mobile phones. In conclusion, Kuznekoff and Titsworth (2013) maintain that students who use their mobile phones during class lectures tend to write down less information, recall less information, and perform worse on a multiple-choice test than those students who avoid using their mobile phones during class. Similarly, Kraushaar \& Novak (2010) explored laptop use during class lecture and found a strong, negative correlation between student uses of instant messaging services and quiz averages, project grades, and final exam grades. Wei et al. (2012, as cited in Kuznekoff and Titsworth, 2013) also observed that frequent texting during class influenced students' ability to attend to material being covered in that class and potentially results in decreased perceived cognitive learning. Results of the current study contribute new information to this body of literature by showing that students' self-reports and perceptions correlate with previous observations.

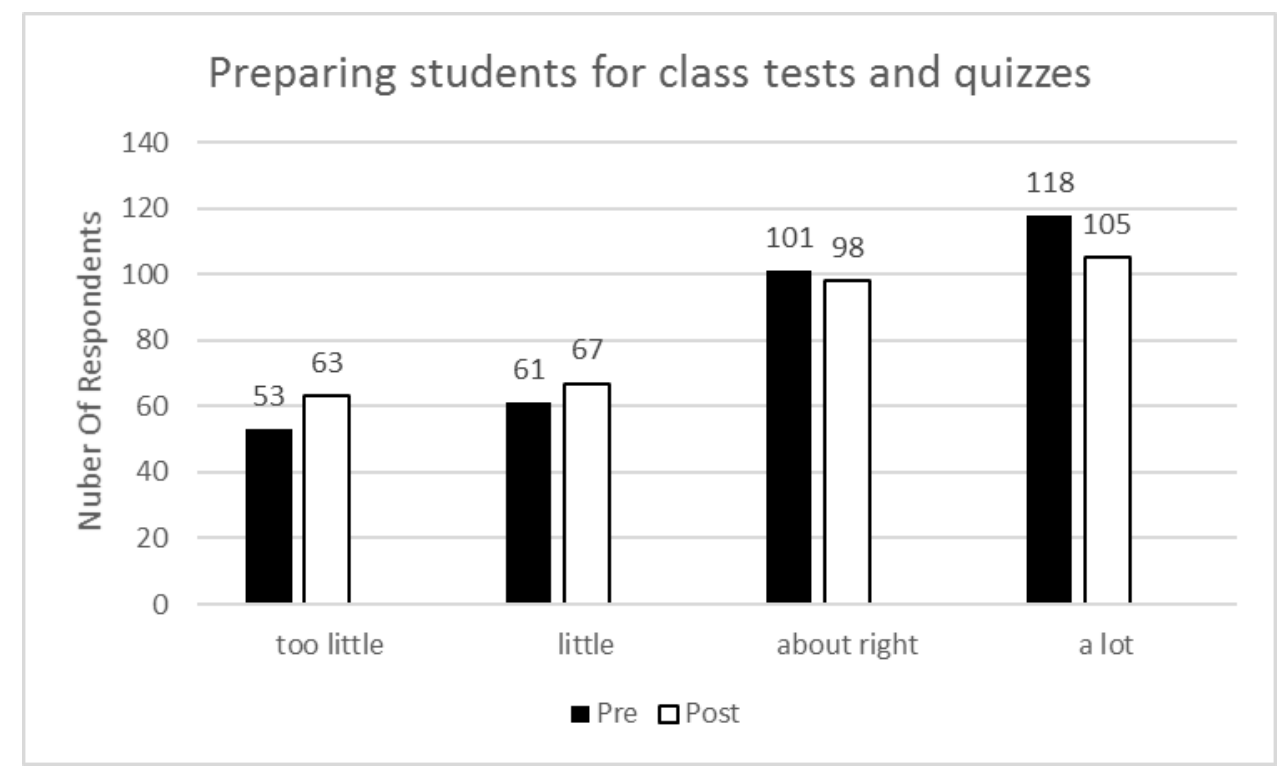

Figure 7. Students' perceived impact of devices on preparing them for class tests and quizzes (Q. 3

\section{Discussions}

The study has presented interesting results into ongoing practices of mobile devices in Iran which can serve as a step to develop learning in formal EFL contexts. Mobile devices have proved useful in supporting learning. There are numerous advantages reported by EFL learners in other researchers' studies. While the main role of mobile devices is communication, it appears to be able to support EFL teaching and learning by improving learners' motivation, language 
skills, vocabulary and grammar. Among the Iranian EFL learners surveyed, however, there are some differences in mobile device use according to their attitudes towards the type of mobile device.

These findings are consistent with the opinion of those scholars who believe that the use of computer plays a significant role in teaching and learning, especially when used as supplementary to the traditional classroom instruction (BangertDrowns et al., 1985; Lungberg, 1995; Marzban, 2011; Sotoudehnama, 2014; Leis et al., 2015) According to Sue et al. (2000), computers enable teachers to change the pace of their instruction to meet the needs of individual students and allow them to teach and emphasize particular skills and strategies as well. As stated by Soe et al. (2000) computer assisted instruction can also increase the possibility of improving students' motivation and will provide the students with immediate feedback. In a similar vein, Leis et al. (2015), concluded that students who were encouraged to use their smartphones during class were inclined to study more in their free time as well as show signs of autonomy by taking charge of their learning and consider ways to improve their own study habits and English proficiency.

Nevertheless, these findings are inconsistent with the opinion of some other scholars who argue against the effectiveness of applying computers in education. According to Gulley (2003), teachers should be aware of the importance of human emotions and they should take it into consideration. She states that the students need human support and the rapid development of computer technology should not interfere with it.

Specifically, the survey findings indicated that Iranian EFL learners had more positive attitudes towards tablets than smart phones. According to Forrester research (2010), tablets are generally preferred over smart phones due to their larger size and efficiency, and continue to outsell desk top computers simply because smart phones and desk tops almost work the same. This was evident in students' reports about the priority of tablets over lap tops. There are similarities between the findings of this study and those of other studies in both EFL and ESL contexts.

Students' comfort and enjoyment did not appear to increase in this investigation due to the miscellaneous technical problems turning up while working with those devices. The findings related to these problems in this study are in accord with similar findings of other researchers' studies. Learners in many other studies have frequently reported that technical problems prevented them from enjoying the practices. In general, it can be concluded that EFL learners' dissatisfaction with mobile devices, despite their initial positive attitudes, is due to their inability in applying smart phones and tablets to learning in formal contexts.

As for reading comprehension, unlike reading speed, the findings indicated that students' expectations regarding the impact of smart phones and tablets were met. Although reading comprehension and reading speed are related, in the case of mobile devices it appears that success in the former does not depend much on the latter. Another possibility is that reading speed may not be as important as reading comprehension to students in general and goal-oriented students in particular.

Students' abundant comments about progress in vocabulary and spelling suggest that tablets and smart phones proved effective in developing these language components. Overall, findings indicated that mobile devices had more positive impact on linguistic categories of the study than psychological categories. There are two possibilities. The first possibility is that students' unfamiliarity with the use of mobile devices in formal contexts encourages them to take a negative view of these devices. Learners' initial positive attitudes in pre-survey questions and a shift to negative comments in post-survey questions attest to this possibility. The second possibility is that learners in EFL contexts, like Iran, resist novelty in education. This resistance, of course, is evident in all aspects of Iranian life and culture, and the application of mobile devices to learning in classroom context is not an exception.

In conclusion, despite unfamiliarity and resistance problems, ample empirical evidence from many formal contexts has shown that these problems would be gradually overcome as soon as EFL learners become immersed in mobile technology in formal contexts as much as they already do in informal contexts.

\section{Conclusion}

In closing, there is still much to be learned about using electronic devices in EFL classes. It should not be forgotten that smartphones and tablets' role in teaching is solely a teaching aid. What is of great importance is not the use of technology per se, but the quality of what is done with this medium. According to Gulley (2003), education can nurture and develop students' imagination, curiosity, and creativity, and the use of computer technology plays an important role in education which can help students to reach their full potentials. Education seeks to prepare the students to go into the world and the use of computer technology can be considered as a positive complement to bridge the gap between the world of education and the world of technology.

While smart phones and tablets do not currently replace traditional tools in EFL settings, they can supplement them. Education has become more learner-centric as students are given a choice of what device to use and how they want to use it. It is clear from this study that EFL students, just like their counterparts in English speaking countries, would value technology-enhanced language learning if the obstacles were eliminated. EFL students' access to smart phones and tablets was not only a positive experience for many participants, especially in the areas of language skills and components as well as increased confidence, but it enabled them to stay on top of things, get the most of their time, and be more motivated to learn as well. The mobile learning environment changes the monotonous way of teaching in the traditional lecture classrooms. Educators need to continue to look for new ways to motivate students in order to maximize their learning, and one way to accomplish this objective may be by incorporating mobile devices in a new, but limited, way in all Basic and General English classes.

Further research can address several issues left unresolved by this study. In future studies, one might consider the students and teachers' attitudes towards the effect of smartphones and tablets on other macro skills, such as, listening, writing, and speaking. The variables of age, gender, and levels of language proficiency can be investigated as well. Non-English major students and students of other languages can also be examined in this regard. 
This study also indicated that most participants have access to smartphones and tablets and use them frequently. However, this does not mean that students and instructors are ready to use such mobile devices with adequate ease and functionality. Nor does the availability of mobile devices guarantee their effective use in education (Corbeil \& ValdesCorbeil, 2007). The use of ever-changing mobile technology in language learning across the country is not without its obstacles. The cost of tablet computers, the versatility of the mobile devices, lack of connectivity to the internet, lack of training, administration and lack of reasonable pedagogical justifications for mobile language learning add to the dilemma of mobile learning and may cause the programs not to live up to their objectives, leading to total frustration. Therefore, further research should focus on these demanding areas with the aim of helping teachers and learners to enhance the quality of education in the future.

The present study had some limitations. The sample size was limited to 333 undergraduate students. Other university undergraduates with different grade levels and gender could have varying patterns of mobile device ownership and usage. However, the available findings are largely in line with other related studies, suggesting that the sample is not completely unrepresentative. Thus, further research should focus on larger sample sizes including a wide range of university students as well as instructors across the nation, with significant variables such as socio-economic background and life circumstances of students. Another limitation was that the survey data were self-reported by the students. Thus the students might have not reported what they actually do with their electronic devices.

\section{References}

Agah, T.K. \& Ayse, A. (2011). Differences between m-learning (mobile learning) and e-learning, basic terminology and usage of m-learning in education. In A. Arikan, H.S. Sarac, O. Sert, M. Caner, \& S. Cevik (Eds.), Procedia-Social and Behavioral Sciences: Vol. 15. 3rd World Conference on Educational Sciences, pp. 1925-1930.

Ally, M., Schafer, S., Cheung, B., McGreal, R., and Tin, T (2007). "Use of Mobile Learning Technology to Train ESL Adults," in Proceedings of the $6^{\text {th }}$ Annual International Conference on Mobile Learning, Melbourne, Australia, pp. 7 12.

Bangert-Drowns, R. L., Kulik, J. A., \& Kulik, C. L. C. (1985). Effectiveness of computer-based education in secondary schools. Journal of Computer-Based Instruction, 12(1), 59-68.

Bruck, P. A., Motiwalla, L., \& Foerster, F. (2012). Mobile learning with micro-content: A framework and evaluation" (2012). Proceedings of the BLED 2012, Slovenia, 25, Paper 2. Retrieved September, 21, 2012, from http://aisel.aisnet.org/bled2012/2

Carr et al. (2011). Perceived benefits of technology enhanced language learning in beginning language classes. The IALLT Journal, 41 (1), pp. 36-52.

Chinnery, G. M. (2006). Emerging technologies going to the MALL: Mobile Assisted Language Learning. Language Learning \& Technology, 19(1), pp. 29-39.

Corbeil, J. R., \& Valdes-Corbeil, M. E. (2007). Are you ready for mobile learning? EDUCAUSE Quarterly, 30(2), $51-58$.

Cowan, N. (2001). The magical number 4 in short-term memory: A reconsideration of mental storage capacity. Behavioral and Brain Sciences, 24(1), pp. 87-114.

Dias, J. (2012a). Cell phones in the classroom: Boon or bane? [Part 1]. C@lling Japan: The Newsletter of the JALTCALL Special Interest Group, 10(2), pp. 16-22.

Dias, J. (2012b). Cell phones in the classroom: Boon or bane? [Part 2]. C@lling Japan: The Newsletter of the JALTCALL Special Interest Group, 10(3), pp. 8-13.

Girón-García, C. (2015). Literacy and technologies in EFL settings: Fostering reading comprehension on the Internet. Bellaterra Journal of Teaching \& Learning Language \& Literature. Vol. 8(2), 69-100.

Ghizan S. (2012). The Effect of Instructional Reading Software on Developing English Reading Speed and Comprehension for IT University Students. USA, Xlibris Corporation.

Gould, J. D. \& Grischkowsky, N. (1986). Does visual angle of a line of characters affect reading speed? Human Factors, 28(2), 165-173.

Gulley, P. K. (2003). Pros and cons of computer technology in the classroom. Retrieved April 4, 2012, from http://edweb.fdu.edu/anyfil e/MattewsC/article2.doc

Internet World Stats (2015). Usage and Population Statistics [Data file]. Internet usage in the Middle East. Retrieved from http://www.internetworldstats.com/me/ir.htm

Jee, M.J. (2011). Web 2.0 technology meet mobile assisted language learning. The IALLT Journal, I41(1), pp. 161-175. Just, M., \& Carpenter, P. (1987). Speed reading. The psychology of reading and language comprehension, pp. 425-452.

Kak, A. V. (1981) Relationships between readability of printed and CRT-displayed text. Proceedings of Human Factors Society - 25th Annual Meeting, 137 - 140.

Kyanka-Maggart, J. (20130. iPads, motivation, self-efficacy, engagement in upper elementary school mathematics (Doctoral dissertation). Retrieved from https://www.bakeru.edu/images/pdf/SOE/EdD_Theses/Kyanka-

Maggart_Jessica.pdf 
Kiernan, P. J., \& Aizawa, K. (2004). Cell phones in task based learning: Are cell phones usefull language learning tools? ReCALL, 16(1), pp.71-84.

Kothaneth, S., Robinson, A., \& Amelink, C. (2011). Tablet PC support of students' learning styles. Retrieved September 21, 2012, from http://www.iiis.org/CDs2011/CD2011SCI/IMETI_2011/PapersPdf/FA805DB.pdf

Kovachev, D., Cao, Y., Klamma, R. and Jarke, M. (2011) 'Learn-as-you-go: New ways of cloud-Based micro-learning for the mobile web. In H.Leung, et.al, (Eds.), ICWL 201, (pp. 51-61). Berlin; Springer-Verlag.

Kraushaar, J. M., \& Novak, D. C. (2010). Examining the effects of student multitasking with laptops during the lecture. Journal of Information Systems Education, 21, 241251.

Kuznekoff, J. \& Titsworth, S. (2013). The impact of mobile phone usage on student learning. Communication Education, 62 (3), pp. 233252.

Leis, A., Tohei, A., \& Cooke, S. (2015). Smartphone assisted language learning and autonomy. International Journal of Computer-Assisted Language Learning and Teaching, 5(3), 75-88.

Levy, M., \& Kennedy, C. (2005). Learning Italian via mobile SMS. In A. Kukulska-Hulme \& J. Traxler (eds.), Mobile Learning: A handbook for Educators and Trainers. London: Taylor and Francis.

Marzban, A. (2011). Improvement of reading comprehension through computer-assisted language learning in Iranian intermediate EFL students. Procedia Computer Science, 3, 3-10.

Mielo, G. (2005). The medium is the moblog. ETC: A Review of General Semantics. 62(1), pp. 28-35.

Mockus, L., Dawson, H., Edel-Malizia, S., Shaffer, D., Sung, J., \& Swaggerty, A. (2011). The impact of mobile access on motivation: Distance education student perceptions. Retrived September 10, 2012, from http://learningdesign.psu.edu/research/MLRTWhitePaper.pdf

Muter, P., Latremouille, S. A., Treurniet, W. C. \& Beam, P. (1982). Extended reading of continuous text on television screens. Human factors, 24 (5), 501-508.

Najmi, K. (2015). The effect of mobile-assisted language learning (MALL) on guided writing skill of Iranian upperintermediate EFL learners. Journal of Applied Linguistics and Language Research, 2(4), 42-52.

Oz, H. (2013). Prospective English teachers' ownership and usage of mobile devices as m-learning tools. Procedia Social and Behavioral Sciences, 141, 1031 - 1041.

Shah, A. (2016). Tablets vs. laptops vs. smartphones [Data file]. Retrieved from http://www.pcworld.com/article/243132/tablets_vs_laptops_vs_smartphones.html

Stearns, Susan C. (2012). Integration of technology into the classroom: Effects on reading comprehension. Research Papers, Paper 248.

Smedshammar, H., Frenckner, K. ,Nordquist, C. and Romberger, S. (1989) Why is the difference in reading speed when reading from VDUs and from paper bigger for fast readers than for slow readers? Paper presented at WWDU 1989, Second International Scientific Conference, Montreal.

Rosenberg, M. J. (2010). Marc my words: Thinking about mobile learning in the age of iPad. Learning Solutions Magazine. Retrieved September11, 2012, from http://www.learningsolutionsmag.com/articles/477/marc-my-wordsthinking-about-mobile-learning-in-the-age-of-iPad

Shearer, R. L. (2010). Philosophies and theories at the basis of student-centered educational models: Where theory and practice meet in instructional design for distance education. Paper presented at the XV International Congress on Technology and Distance Education. Retrived September 11, 2012, from learningdesign.psu.edu/research/MLRTWhitePaper.pdf.

Simon, H. A. (1974). How big is a chunk? Science, 183, pp. 482-488.

Sheehy, K., Kukulska-Hulme, A., Twining, P; Evans, D., Cook, D \& Jelfs, A. with Ralston, J., Selwood, I., Jones, A., Heppell, S., Scanlon, E., Underwood, J., \& McAndrew, P. (2005). Tablet PCs in schools: A review of literature and selected projects. Coventry, UK: British Educational Communications and Technology Agency, ICT Research.

Soe, K., Koki, S., \& Chang, J. M. (2000). Effect of computer-assisted instruction on reading achievement: A metaanalysis. Washington, DC: Office of Educational Research and Improvement.

Sole, R.C, Calic, J., and Neijmann, D. (2010). A social and self-reflective approach to MALL. ReCALL, 22, pp. 39-52.

Song, Y., \& Fox, R. (2005). Integrating m-technology into Web-based ESL vocabulary learning for working adult learners. Wireless and Mobile Technologies in Education (IEEE). Tokushima, Japan: IEEE Computer Society.

Sotoudehnama, E., \& Dehghan, H. (2013). The effect of call software on Iranian EFL learners' reading comprehension. Iranian Journal of Language Issues, 1(1), 25-30.

Thronton, P., \& Houser, C. (2002). M-learning in transit. In P.Lewis (Eds.), The changing face of CALL (pp. 229-243). Lisse, The Netherlands: Swets and Zeitlinger.

Thronton, P., \& Houser, C. (2003). Using mobile web and video phones in English language teaching: Projects with Japanese college students. In B. Morrison, C. Green, \& G. Motteram (Eds.), Directions in CALL: Experience, experiment \& evaluation (pp. 207-224). Hong Kong: English Language Center, Hong Kong Polytechnic University.

Thornton, P., \& Houser, C. (2005). Using mobile phones in English education in Japan. Journal of Computer Assisted Learning, 21(3), 217-228. 
Uther, M., Zipetria, I., Uther, J., \& Singh, P. (2005). Mobile adaptive CALL (MAC): A case study in developing a mobile learning application for speech/audio language training. Wireless and Mobile Technologies in Education (IEEE). Tokushima, Japan: IEEE Computer Society.

Vanwelsenaers, M. (2012). Students using their own technology device in the classroom: can "BYOD" increase motivation and learning? (Master's thesis). Retrieved from https://www.nmu.edu/education/sites/DrupalEducation/files/UserFiles/Vanwelsenaers_Marc_MP.pdf

Wei, F.-Y. F., Wang, Y. K., \& Klausner, M. (2012). Rethinking college students' self-regulation and sustained attention: Does text messaging during class influence cognitive learning? Communication Education, 61, 185204.

Woodill, G. (2011). The mobile learning edge: Tools and technologies for developing your teams. New York: McGrawHill Professional.

Wright, S., Fugett, A., \& Caputa, F. (2013). Using e-readers and internet resources to support comprehension. Educational Technology \& Society, 16 (1), 367-379.

Wright, P. \& Lickorish, A. (1983). Proof-reading texts on screen and paper. Behaviour and Information Technology, 2 , (3), 227-235.

Zarei, A.A. (2012). The effects of STAD and CIRC on L2 reading comprehension and vocabulary learning. Frontiers of Language and Teaching, 3, pp. 161-173.

\section{Appendices}

Appendix A

General Questions

Please fill in or check the appropriate information.

Age----------------years $\quad$ Sex: $\quad$ Male $\quad \square$ Female

Course Name:

I. Mobile Device Questions

1. Do you have any of the following mobile device/s? Check all that apply.

A) Smart-phone (IPhone, Android, etc.)

B) Tablet (I Pad, Galaxy, etc.)

C) Both smart phone and tablet

If yes, please answer the following questions.

2. How comfortable are you using your mobile device(s)?

A) Very comfortable

B) Somewhat comfortable

C) It is too complicated

3 . How long have you used your mobile device?

A) Less than 1 year

B) $1-2$ years

C) 2-3 years

D) More than 3 years

4. What role does novelty play in your mobile device use?

A) I always chase the newest gadgets

B) If it's a popular device I'll buy it

C) If it's a useful device I'll buy it

D) Novelty does not play a role

5. What do you use your mobile device for? Check all that apply.

A) Making phone calls

B) Text messaging

C) Learning English

E) Reading articles, books, articles, online content

F) Watching video

G) Playing games

I) Taking, sending or viewing pictures

J) Taking, uploading or watching videos

6. If you access the internet on your mobile device, how much time (per day) do you spend online?

A) Less than 15 minutes

B) Up to 1 hour

C) 1-2 hours

D) More than 2 hours

7. If you have a mobile device, can you live without it?

A) Yes

B) No

8. How many hours a day do you use your mobile device?
A) Less than 1 hour
B) 1-2 hours
C) 2-3 hours
D) 3 hours or more 
Appendix B

\section{Pre-Survey}

1. Please fill in or check the appropriate information.

2. How confident do you feel about using the following? (Check each item with an X.)

\begin{tabular}{|l|l|l|l|l|}
\hline & $\begin{array}{c}\text { Very } \\
\text { confident }\end{array}$ & $\begin{array}{c}\text { Somewhat } \\
\text { confident }\end{array}$ & $\begin{array}{c}\text { Not very } \\
\text { confident }\end{array}$ & $\begin{array}{c}\text { Not at all } \\
\text { confident }\end{array}$ \\
\hline Smart Phone & & & & \\
\hline Tablet & & & & \\
\hline
\end{tabular}

Rate your opinion on the following items: 1234 (1=not much or none and 4= a lot or a great deal)

3. What do you predict the benefit of using mobile device/s in English classes will be?

\begin{tabular}{|c|c|c|c|c|}
\hline 1. developing reading speed & 1 & 2 & 3 & 4 \\
\hline 2. improving reading comprehension & 1 & 2 & 3 & 4 \\
\hline 3. improving spelling & 1 & 2 & 3 & 4 \\
\hline 4. developing vocabulary & 1 & 2 & 3 & 4 \\
\hline 5. preparing students for class tests and quizzes & 1 & 2 & 3 & 4 \\
\hline 6. improving motivation & 1 & 2 & 3 & 4 \\
\hline
\end{tabular}

Rate your opinion on the following items: 1234 (1=not much or none and $4=$ a lot or a great deal)

\begin{tabular}{|c|c|cccc}
7. & How much do you enjoy using your device/s? & 1 & 2 & 3 & 4 \\
\hline
\end{tabular}

4. Briefly describe your experiences -using your mobile device/tablet as a student.

\section{Appendix C}

\section{Post-Survey}

I. Please fill in or circle the appropriate information.
Age-
-years
Sex:
$\square$ Male
$\square$ Female

Course Name:-

Teacher's Name: .

1. What is your first language?

2. Have you attended any English classes before being accepted to university?

3. Why do you learn English?

4. How confident do you feel about using the following? (Check each item with an X.)

\begin{tabular}{|l|c|c|c|c|}
\hline & $\begin{array}{c}\text { Very } \\
\text { confident }\end{array}$ & $\begin{array}{c}\text { Somewhat } \\
\text { confident }\end{array}$ & $\begin{array}{c}\text { Not very } \\
\text { confident }\end{array}$ & $\begin{array}{c}\text { Not at all } \\
\text { confident }\end{array}$ \\
\hline Smart Phone & & & & \\
\hline Tablet & & & & \\
\hline
\end{tabular}

Rate your opinion on the following items: 1234 (1=not much or none and 4= a lot or a great deal) AFTER mobile learning experiences.

5. What was the benefit of using mobile devices in your class for

\begin{tabular}{|ll|lll|}
\hline $1 . \quad$ developing reading speed & 1 & 2 & 3 & 4 \\
\hline $2 . \quad$ improving reading comprehension & 1 & 2 & 3 & 4 \\
\hline $3 . \quad$ improving spelling & 1 & 2 & 3 & 4 \\
\hline $4 . \quad$ developing vocabulary & 1 & 2 & 3 & 4 \\
\hline $5 . \quad$ preparing students for class tests and quizzes & 1 & 2 & 3 \\
\hline 6. & improving motivation & 1 & 2 & 3 \\
\hline
\end{tabular}


Rate your opinion on the following items: 1234 (1=not much or none and 4= a lot or a great deal) AFTER mobile learning experiences.

\begin{tabular}{|l|lll|}
\hline 7. How much did you enjoy using your device/s? & 1 & 2 & 3 \\
\hline
\end{tabular}

6. Please answer the following questions.

I. What were the positive aspects of using your mobile device/s?

II. What were the negative aspects of using mobile device/s?

III. Briefly describe how you plan to use mobile devices in the future.

\section{Appendix D}

General Questions
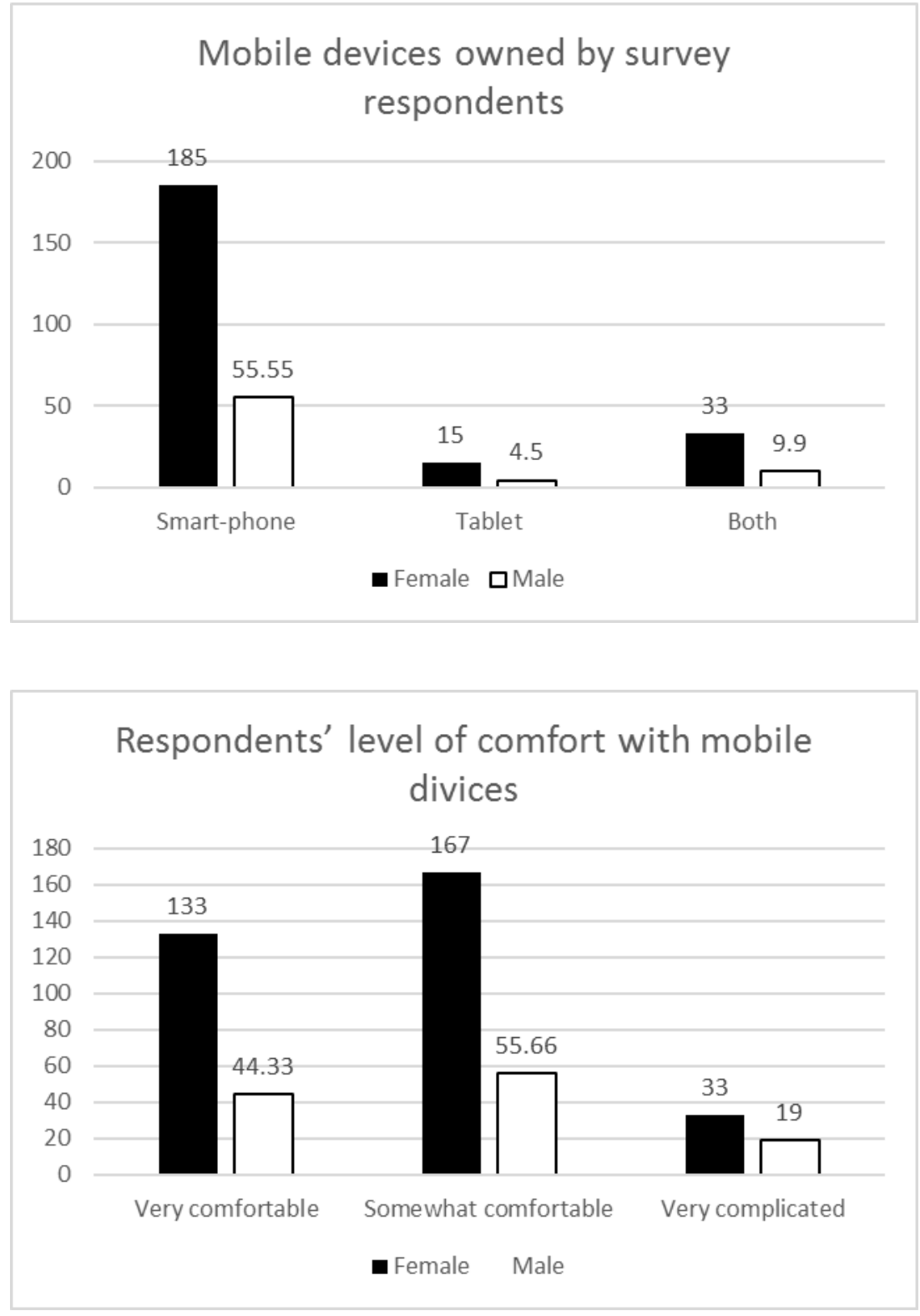
How long respondents have been using mobile devices

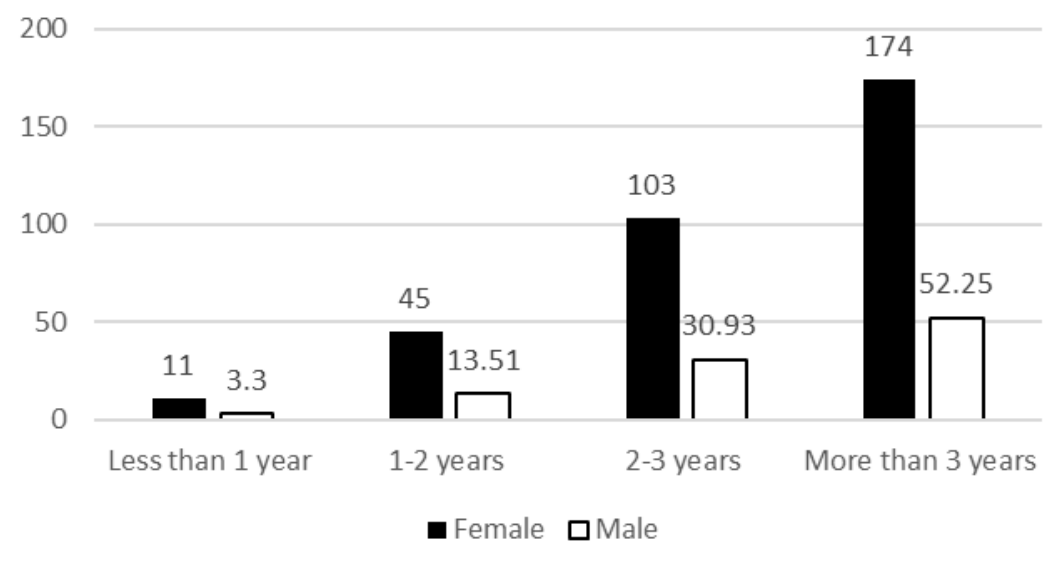

The role of novelty in respondent use of mobile devices

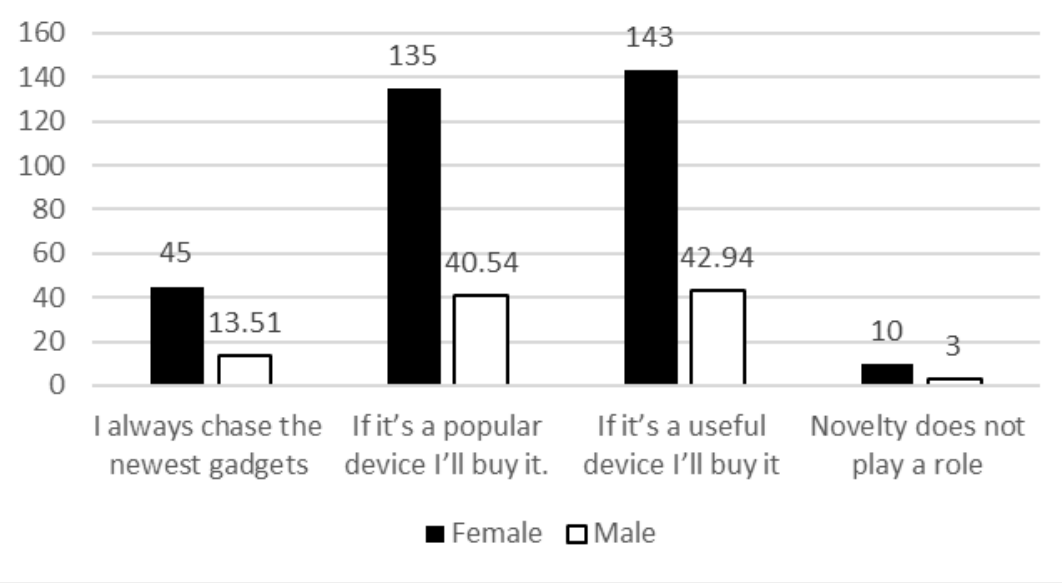

Mobile device use by survey respondents

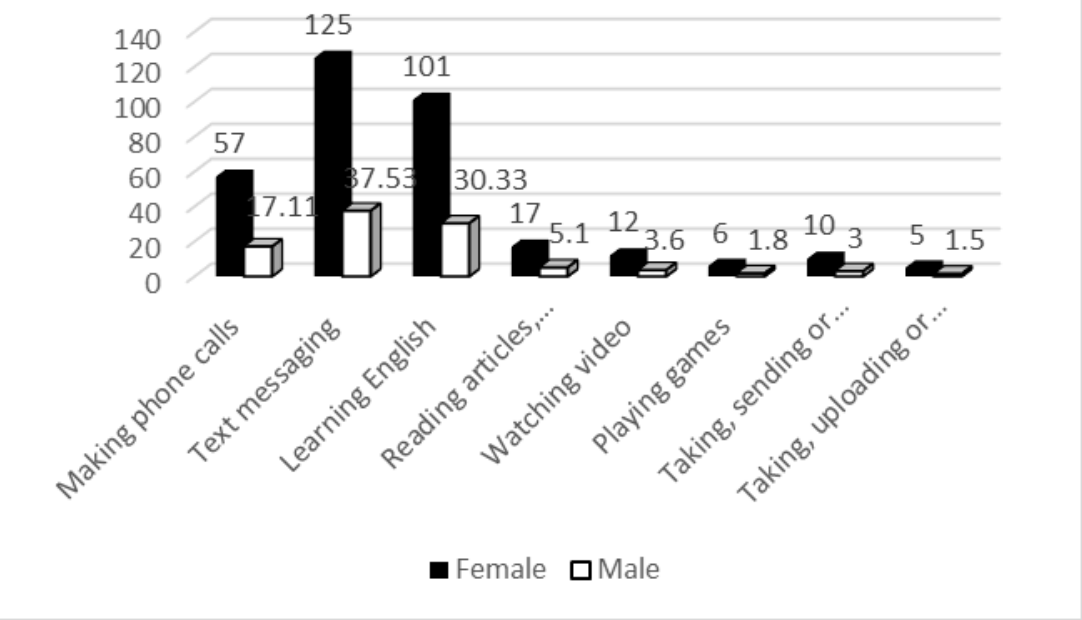


Respondent time spent online with mobile devices

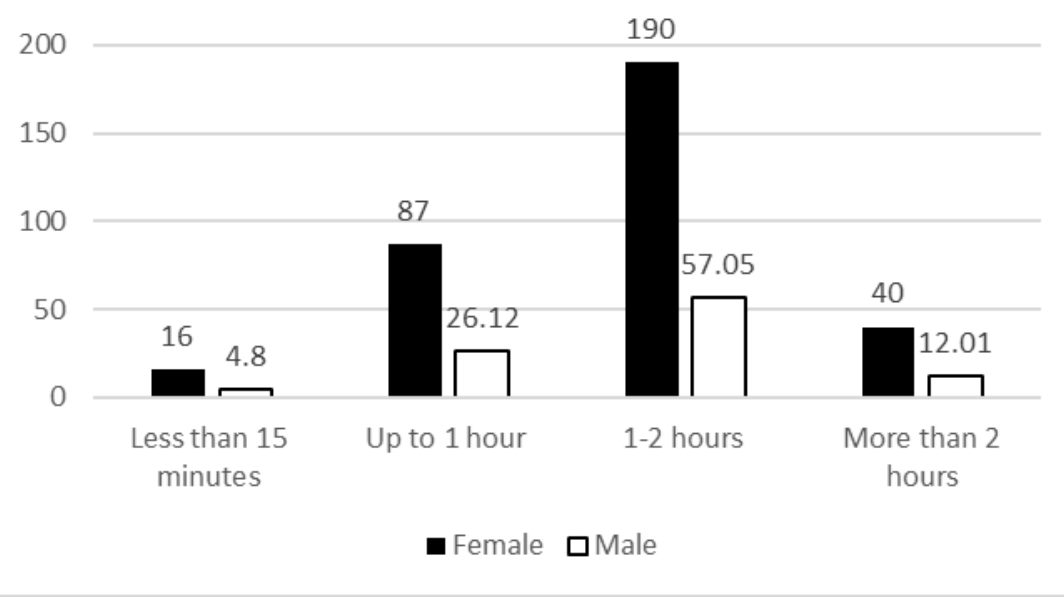

The level of respondent dependency on mobile devices
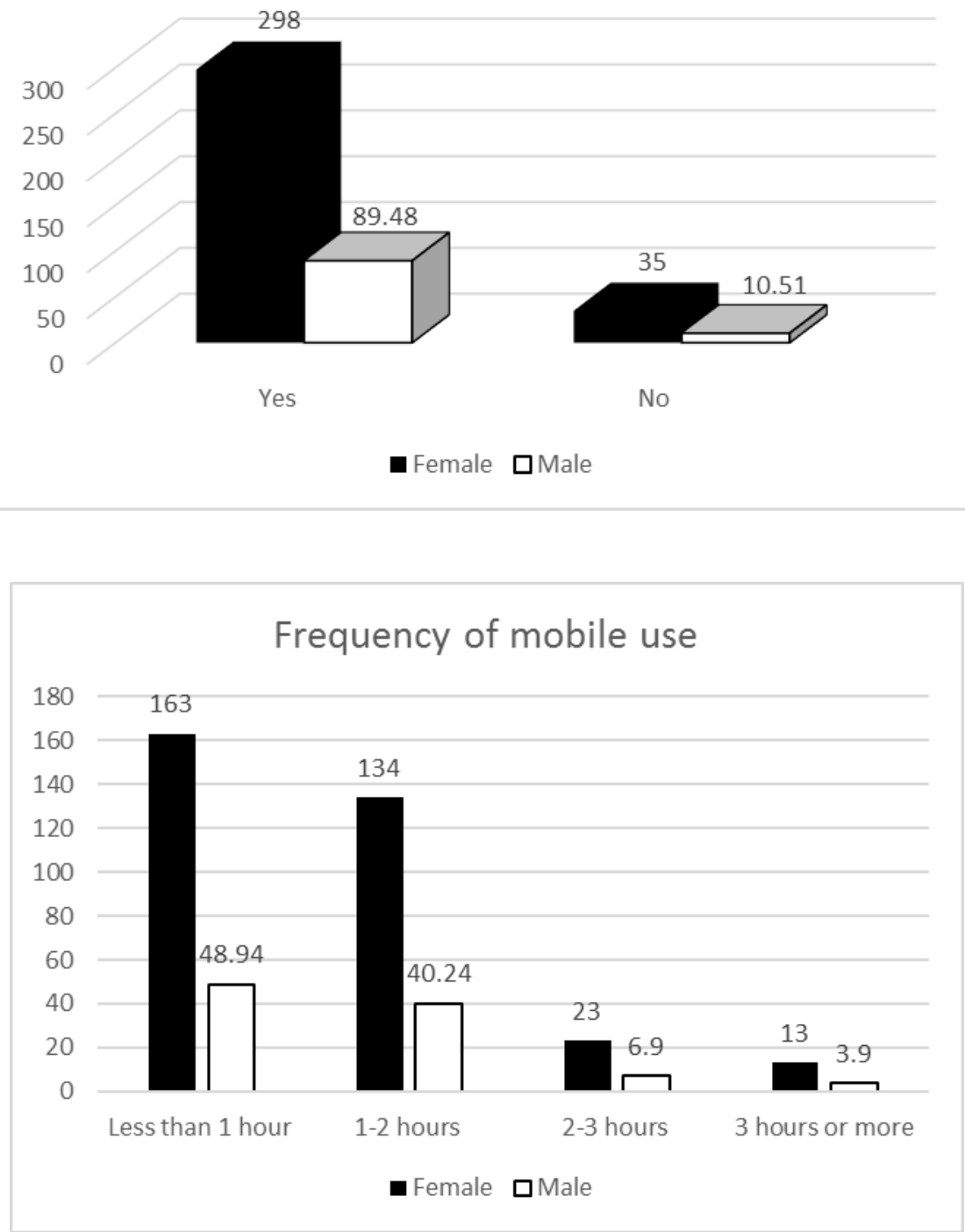